\title{
Hemodynamic consequences of different ventilation methods used in lung surgery
}

\author{
Hanna Misiołek ${ }^{1}$, Dariusz Budziński², Jacek Karpe ${ }^{1}$, Piotr Knapik ${ }^{3}$, Damian Czyżewski ${ }^{4}$ \\ ${ }^{1}$ Department of Anesthesiology and Intensive Care, Chair of Anesthesiology, Intensive Care, and Emergency \\ Medicine, School of Medicine with the Division of Dentistry in Zabrze, Medical University of Silesia in \\ Katowice \\ ${ }^{2}$ Department of Anesthesiology and Intensive Care, University Hospital, School of Medicine with the Division of Dentistry \\ in Zabrze \\ ${ }^{3}$ Department of Cardiac Anesthesia and Intensive Care, Chair of Anesthesiology, Intensive Care, and Emergency Medicine, \\ School of Medicine with the Division of Dentistry in Zabrze, Medical University of Silesia in Katowice \\ ${ }^{4}$ Chair and Department of Thoracic Surgery, School of Medicine with the Division of Dentistry in Zabrze, \\ Medical University of Silesia in Katowice
}

Kardiochirurgia i Torakochirurgia Polska 2013; 10 (4): 397-402

\begin{abstract}
Anesthesia techniques used in thoracic surgery are completely different from those used in general surgery, because thoracic surgery requires both effective ventilation and immobilization of the operating area. One lung ventilation (OLV) remains the standard ventilation method used during thoracic surgery procedures. The most frequent position of the patient during thoracotomy is the lateral decubitus position opposite to the operated side. The abovementioned conditions lead to several respiratory, hemodynamic, and oxygenation disturbances. However, high-frequency jet ventilation (HFJV) may be used as an alternative way of ventilation during lung resection. Both ventilation methods provide full or partial immobilization of the operative field, but they result in different hemodynamic effects. Comparing the cardiovascular parameters during OLV and HFJV we can definitely say that HFJV provides better oxygenation and ventilation in comparison to OLV, while maintaining hemodynamic stability.
\end{abstract}

Key words: one lung ventilation, high frequency jet ventilation, cardiovascular system.

One lung ventilation (OLV) remains the standard method of providing ventilation during anesthesia before thoracic surgery procedures. The procedures are usually conducted with the patient in a lateral decubitus position opposite to the operated side, with concurrent opening of the chest (open pneumothorax), which allows for complete or partial

\section{Streszczenie}

Techniki znieczulenia i wentylacji do operacji torakochirurgicznych są zdecydowanie odmienne od stosowanych w chirurgii ogólnej. Standardową metodą wentylacji podczas dużych zabiegów torakochirurgicznych dotyczących miąższu płucnego oraz innych narządów klatki piersiowej jest wentylacja jednego płuca (one lung ventilation - OLV). Najczęściej zabiegi przeprowadza się $\mathrm{w}$ ułożeniu pacjenta na boku przeciwnym do operowanego z równoczesnym otwarciem klatki piersiowej (odma otwarta). To wszystko implikuje zaburzenia mechaniki oddychania, hemodynamiki oraz utlenowania krwi. Alternatywną metodą jest wentylacja wysokimi częstotliwościami (high-frequency jet ventilation - HFJV). Obie metody wentylacji zapewniają całkowite lub częściowe unieruchomienie pola operacyjnego, ale odmienne skutki hemodynamiczne.

Porównując obie techniki wentylacji ze względu na zachowanie się parametrów układu sercowo-naczyniowego, można zdecydowanie stwierdzić, że HFJV zapewniając lepsze utlenowanie i prawidłową wentylację, utrzymuje stabilność hemodynamiczną w porównaniu z wentylacją OLV.

Słowa kluczowe: wentylacja jednym płucem, wentylacja wysokimi częstotliwościami, układ sercowo-naczyniowy.

immobilization of the operating field. Employing this method of ventilation, however, implies a change in the mechanics of breathing, hemodynamics, and blood oxygenation [1].

During one lung ventilation, the priority for the anesthesiologist is to protect the patient from hypoxia, caused primarily by right-to-left intrapulmonary shunting. The fac- 
tors which determine the amount of blood supply reaching the unventilated lung include hypoxic pulmonary vasoconstriction (HPV), the extent of surgical intervention performed on the unventilated (upper) lung, preoperative and intraoperative functioning of the lower lung and the method by which it is ventilated, and proper selection of anesthetic agents. Controlled hypercapnia developed during hypoventilation is an advantageous phenomenon, as it intensifies hypoxic pulmonary vasoconstriction, probably due to the intensification of acidosis. However, uncontrolled progressive hypercapnia becomes a problem, as it increases vascular bed resistance in the lower lung and restricts the redistribution of blood from the unventilated upper lung [2-4].

Blood oxygenation during OLV can be significantly improved by applying continuous positive airway pressure (CPAP) to the upper, unventilated lung. The values of the positive pressures should not exceed $5 \mathrm{~cm} \mathrm{H}_{2} \mathrm{O}$, because using excessive CPAP values results in reducing venous return and cardiac output (CO). In turn, applying positive end-expiratory pressure (PEEP) results in reducing the gradient of the pressure required for preserving normal venous blood flow to the chest, while myocardial compression results in decreased contractility of the cardiac muscle. Compression on the pulmonary vessels limits the inflow of blood into the left ventricle and impedes right heart emptying; as a result, the right ventricle may be dilated, and the interventricular septum may be displaced in the direction of the left ventricle, which causes a decrease in stroke volume (SV) [5]. Elevated intrapulmonary pressure combined with increased airway pressure results in a drop in the tension of the left ventricular muscular lamina, thus reducing preload. The necessary fluid restriction further limits the minute volume of the heart. Impeded lymphatic drainage, resulting in transudate accumulation in the lungs, may negatively influence oxygenation, constituting another hemodynamically detrimental consequence of positive airway pressure [6]. One lung ventilation may be substituted with high-frequency jet ventilation (HFJV). The latter method ensures minimal mobility of the operated lung, lower airway pressures in comparison to classic ventilation (reducing the risk of barotrauma), low values of tidal volume, minimal depressive influence on the circulatory system, reduced intrapulmonary shunting, and the generation of low positive end-expiratory pressure (which is probably responsible for the excellent oxygenation parameters).

The remarkability of high frequency ventilation is associated with the fact that proper pulmonary alveoli ventilation may be achieved with tidal volumes smaller than the volume of airway dead space [7].

HFJV has been employed in the treatment of acute respiratory failure and for ventilating patients with bronchopleural and tracheoesophageal fistulas. It has also been used in laser microsurgery of the larynx and in selected thoracic and cardiac surgery procedures [8-13].

A study by Nevin et al. [14] describes the use of HFJV in a group of 65 patients undergoing thoracic surgery procedures. The technique was employed in some of the patients, while OLV was used in others. The authors observed shorter hospitalization time, lower incidence of postoperative complications caused by pulmonary infections, and significantly better oxygenation parameters with regard to the procedures performed in the HFJV group [14]. In turn, the advantages of substituting OLV with HFJV in pulmonary decortication procedures involving the opening of the chest were raised by Misiołek et al., whose study confirmed that HFJV ensures better operative conditions, shortens the duration of surgery, and significantly reduces intraoperative bleeding [15].

Furthermore, changing the ventilation mode from intermittent positive pressure ventilation (IPPV) to high frequency ventilation (HFV) improves the functioning of the circulatory system and the general condition of patients in life-threatening situations [16-18].

In everyday practice, high-frequency jet ventilation has been used at the Department of Anesthesiology and Intensive Care of Clinical Hospital No. 1 in Zabrze since 2004; it is a promising method of ventilation in selected thoracic surgery procedures and is worthy of being propagated further [19-21].

There are still few reports pertaining to the use of HFJV during thoracic surgery procedures; however, the available studies indicate that the use of bilateral high frequency ventilation may be an alternative for the widely used method of one lung ventilation (OLV), as it provides proper conditions of blood oxygenation and low respiratory pressures, as well as stable cardiovascular parameters, most likely due to the use of small tidal volumes.

Hemodynamic monitoring allows for the observation of the reactions of the cardiovascular system to therapeutic interventions. The hemodynamic condition of patients qualified for high-risk lung resections can be evaluated based on the analysis of parameters obtained by noninvasive methods, singular parameters of bodily function, or with the help of various invasive techniques, e.g. SwanGanz catheterization. The obtained data allow for the active prediction of hemodynamic stability "crises" and provide control during analgesia. Due to the cost and risk associated with invasive monitoring techniques, many high-risk patients, especially those who cannot undergo cardiac surgery procedures, are deprived of proper monitoring.

The development of alternative non-invasive or minimally invasive techniques of measuring the hemodynamic condition of the circulatory system allows physicians to monitor heart function continuously, and, in the case of some devices, in real time [22]. The evaluation of cardiac output (CO), i.e. the volume of blood pumped into the circulation within the time interval of one minute, constituting the product of stroke volume (SV) and heart rate (HR), is reliable and clinically useful. Estimated left ventricular stroke volume, i.e. the estimated volume of blood pumped during one systole, is calculated based on heart rate and estimated cardiac output, in accordance with the following equation: $\mathrm{SV}=\mathrm{CO} / \mathrm{HR}$. It is determined by the combination of three factors:

- preload, i.e. the end-diastolic volume of the left ventricle,

- contractility, i.e. the strength of myocardial contractions, and

- afterload, which is the resistance against which the volume of the left ventricle is ejected. 
Cardiac output constitutes the primary compensation mechanism triggered in response to a drop in oxygenation. It is a parameter of critical significance in terms of determining whether tissue oxygenation is adequate. Although cardiac output changes reflect physiological changes, it is the finding of the causes of these changes and their treatment that is of fundamental importance.

However, it should be stressed that the primary objective of hemodynamic monitoring is the evaluation of the degree of tissue oxygenation, in accordance with the premises of "goal-directed therapy".

Despite the constant improvement of surgical and anesthesiological techniques, extensive thoracic surgery procedures are often associated with intraoperative or postoperative complications. In many patients treated in intensive care units, depression of myocardial function occurs at unpredictable times as a result of numerous factors. In various clinical situations, therapy is the answer to the occurring hemodynamic changes. The ability to predict the deterioration of hemodynamic conditions resulting from disease progression or surgical injury and the ability to detect unfavorable changes constitute a key factor in preventing hemodynamic "crises" [23, 24].

The primary physiological response to increased tissue oxygen demand or to a drop in oxygen content in arterial blood is the increase of heart rate. It should, however, be mentioned that most circulatory system diseases impede the ability of the heart to produce such a response. As a result, tissues are subject to a secondary compensatory mechanism, utilizing venous oxygen reserves [25].

In consequence, when tissue oxygen supply becomes inadequate, even for a short period of time, lactic acidosis and tissue damage may occur. Thus, the primary objective of providing treatment to critically ill patients is preventing these hypoxic episodes.

In order to prevent hypoxia and control tissue perfusion, conventional hemodynamic monitoring is based on the measurement of systemic pressures and central venous pressure. Although the use of information pertaining to the level of central venous pressure in hemodynamically unstable patients provides additional data on circulating blood volume, the data concerning the patients' circulatory condition is very general and limited. Furthermore, the monitored pressure values reflect tissue oxygenation only to a small degree. As a result, pressure level information may provide an erroneous reflection of the patient's hemodynamic condition. In practice, blood pressure oscillation often appears in the late stages of disorders, resulting from changes in vascular tension, which often occur when hemodynamic changes are already very advanced.

The standard procedure in the case of critically ill patients often involves pulmonary artery (PA) catheterization and thermodilution measurements. This enables the evaluation of myocardial function, including cardiac output and the determinants of stroke volume; moreover, in some cases, it allows the physician to assess the adequacy of tissue oxygenation. The mentioned parameters are ei- ther obtained intermittently (thermodilution catheters introduced into the pulmonary artery) or obtaining them is delayed (catheters for continuous cardiac output measurement). As a result, hypoxia and tissue damage occur while the data obtained with the PA catheter are being analyzed [26]. The clinical limitations of pulmonary artery catheterization are, therefore, associated with the need to balance the advantages offered by the examination to the patient and the risks and costs of using this method.

Pulmonary artery catheterization is of limited use in thoracic anesthesia. This stems from the specificity of this surgical field, in which the activities of the surgeon include the evaluation and/or preparation of the pulmonary artery, combined with the anatomical resection of lung parenchyma (lobectomy, bilobectomy, pneumonectomy). On the other hand, the technique of introducing a balloon catheter into the pulmonary artery is associated with certain randomness with regard to the catheterized side (right or left pulmonary artery). In the case of such operations, one should be certain that the catheterized artery is the one that is opposite to the operated artery, in order to prevent clamping the artery with the balloon and avoid the associated consequences. Moreover, the (accidental) catheterization of the pulmonary artery affected by disease processes of the lung (e.g. neoplastic infiltration) may result in the rupture of the vessel and sudden death of the patient.

The employed treatment, serving the purpose of maintaining proper tissue oxygenation, is not aimed at changing cardiac output, but rather at changing preload, contractility, and afterload, i.e. the resistance against which the volume of the left ventricle is ejected.

Blood volume and systemic vascular resistance are factors which enable the maintenance of arterial pressure values. Ultimately, oxygen supply is controlled by three fundamental factors: hemoglobin concentration, the oxygenation of hemoglobin in the arterial bed, and cardiac output.

As the circulatory system forms a closed circuit, a change in one of the hemodynamic parameters causes compensatory changes in other parameters. For example, an increase of heart rate may compensate unstable or reduced stroke volume, caused by impairments of its basic elements. This points to the fact that cardiac output may be insufficient for the evaluation of the patient's hemodynamic condition.

Therefore, employing a more comprehensive hemodynamic profile, based on the cardiovascular determinants of oxygen supply, may improve the treatment of such disorders.

Taking the above into account, the primary value of non-invasive $\mathrm{CO}$ measurements performed in real time is related to their ability to produce instantaneous, comprehensive measurements of left ventricular flow, enabling the evaluation of the effects of changes in basic hemodynamic parameters, i.e. stroke volume, heart rate, preload, contractility, and afterload. The listed parameters provide information concerning the hemodynamic condition of the patient, allowing the physician to modify the employed treatment and verify its results. 
As mentioned above, there are many factors which can influence the functioning of the cardiovascular system during thoracic surgery procedures. One of them is the method employed for ventilation.

The method that is most frequently used in lung parenchyma resections is one lung ventilation (OLV). The review of the literature which we conducted demonstrated that high frequency ventilation, popular in fields other than thoracic surgery, may offer measurable advantages in the form of proper gas exchange with concurrent low lung mobility, which is the key condition of its usefulness. Besides the apparent advantages of the method, undesirable effects related to its use have also been observed, such as carbon dioxide retention in comparison to standard two lung ventilation (TLV) [27-29].

In many reports, the constant observation and monitoring of $\mathrm{CO}_{2}$ by means of arterial blood gas assessment demonstrated higher values of this parameter during high frequency ventilation [19, 27-29].

Levin et al. [29] analyzed the influence of so-called permissive hypercapnia (PHC) on selected hemodynamic parameters, blood oxygenation, and the degree of intrapulmonary shunt during one lung ventilation. They obtained significantly higher values of parameters such as mean arterial pressure, cardiac output, mean pulmonary artery pressure, and mixed venous blood saturation. Lower peripheral resistance was noted in the PHC group, and non-oxygenated blood shunting was comparable in both groups. The obtained results confirm the vasoconstrictive effect of hypercapnia on pulmonary circulation, which results in the intensification of HPV [30]. Adrenergic activity, resulting from respiratory acidosis, causes an increase in the cardiac index and mean arterial pressure. In turn, respiratory acidosis is another factor which intensifies HPV. Increased levels of carbon dioxide influence contractility and heart rate. This was also observed by Poyhonen et al. [31].

While using HFJV, the efficient elimination of carbon dioxide is conditioned on respiratory cycle frequency, drive pressure (DP), and the ratio between inhalation and exhalation times [30]. High breathing frequency, short inhalation time, and low drive pressures contribute to carbon dioxide retention. Based on a large number of experimental studies, using both animal models and clinical evaluation, it has been determined that the frequency of 150-200 cycles/minute, inhalation time of $30-40 \%$, and DP of $1-1.5 \mathrm{~atm}$ ensure optimal conditions for the successful elimination of carbon dioxide during HFJV [32].

Numerous reports have indicated that high frequency ventilation is a more efficient method, which provides good oxygenation, even in patients with acute respiratory failure or acute respiratory distress syndrome (ARDS). The probable causes of this phenomenon include PEEP at the alveolar level and the specificity of the breathing mixture movements within the lungs [33].

It is unquestionable that different ventilation methods exert an influence on the cardiovascular system and the respiratory system, constituted by the feedback be- tween ventilation, oxygenation, and the condition of the circulatory system. The volume of a single breath and breathing capacity are in a mutual relationship with airway pressure.

High frequency ventilation has been described as less harmful to the circulatory system than IPPV from the moment of its introduction into clinical practice; successive reports comparing the two methods have confirmed this opinion [34, 35].

It is believed that low airway pressures registered while using high respiratory frequencies constitute the primary factor responsible for this state of affairs [36]. Nestorowicz demonstrated that, in the presence of lung pathology and considerable strain on the circulatory system, changing IPPV to HFJV provided a significant improvement in the functioning of both physiological systems [37].

If the relationship between end-diastolic ventricular volume and heart contractility is normal (normal Frank-Sterling curve), deterioration in the diastolic filling of the ventricles results in reduced myocardial contraction strength, which leads to a decrease in stroke volume and cardiac output [38]. The relationship between ventricular filling pressures and airway pressures is proportional. Studies by Misiołek et al., analyzing the results of minithoracotomies, demonstrated higher cardiac contractility and significantly lower drops in left ventricular stroke volume toward the end of ventilation in the group of patients undergoing anesthesia with HFJV, in comparison to OLV [21]. This is probably a result of the higher intrapulmonary resistances obtained in the OLV group.

The increase of heart rate by as much as $25 \%$ of the initial values can persist for as long as 2 weeks after lung parenchyma resections. Together with the increase in heart contractility, these changes confirm the Frank-Starling law with regard to the right ventricle of the heart, maintaining stroke volume at a constant level. With regard to the right ventricle, the said law applies to pulmonary artery pressures up to $60 \mathrm{~mm} \mathrm{Hg}$. Crossing this threshold results in the development of right ventricular dilatation, right atrial dilatation, and tricuspid valve insufficiency [39].

The above studies are complemented with the work of Weber, who observed that HFJV does not reduce stroke volume, not even in patients with heart failure, because of the demonstrated advantages of this ventilation method, namely the reduction of afterload, resulting from lowered intrapulmonary pressure [40]. The evaluation of TSVR (total systemic vascular resistance), which is a type of afterload, conducted by Misiołek et al. [21], yielded lower values during high frequency ventilation, which corroborates the aforementioned findings.

The stabilizing effect of HFJV on the dynamics of circulation is further confirmed by a study of Fusciardi et al., conducted on a group of critically ill patients in cardiogenic shock. The authors obtained higher values of mean arterial pressure, cardiac index, and left ventricular stroke volume in the group of patients treated with high frequency ventilation, and considered this method of respiratory support to be the treatment of choice in this patient group [41]. 
Although patients undergoing lung surgery do not constitute a group that would be comparable to the patients included in Fusciardi's study, the results obtained by Misiołek et al. [21], namely the higher values of systemic pressures and cardiac output obtained using high frequency ventilation at selected measurement points, will become the basis for accepting this method as worthy of use for cardiac patients.

Changing HFJV to IPPV may result in a decrease of arterial pressure and pulmonary artery occlusion pressure, as confirmed by British researchers, who conducted a study on a group of cardiac surgery patients without any lung pathologies [42]. The degree of expected disorders in the case of patients with impaired lung function, such as patients undergoing thoracic surgery procedures, can only be surmised.

An attempt to explain the advantages of HFPPV (highfrequency positive-pressure ventilation) over IPPV without PEEP was made by Smith and Klain in their pioneering report. They suggested that each jet pulsation increases venous return to the left heart and results in a form of counterpulsation in the pulmonary artery [43]. It is one of the theories explaining the efficiency of gas exchange in HFJV, and perhaps it can be used in the search for the reasons behind the "better" hemodynamic condition of patients undergoing high frequency ventilation.

Research conducted by Misiołek et al. [21] revealed significant differences between patient groups with regard to arterial pressures in the final stages of the procedure and ventilation; significantly higher values were obtained in the HFJV group. Excessive lung distension with high drive pressures in HFJV and increased I : E ratio may result in the development of an air trap and may weaken ventricular systolic function by increasing right ventricular afterload or by causing direct pressure on the heart, reducing right ventricular filling [44]. This undesired effect of jet ventilation is one of the reasons for setting relatively low drive pressures. The effects of using high respiratory pressures during lung expansion were described by Tusmann et al. [45] and Misiołek et al. [20]. One of the described consequences is a significant reduction in the values of systemic pressures. During one lung ventilation, the non-operated (lower) lung should be provided with tidal volume of approximately $10 \mathrm{ml} / \mathrm{kg}$ in order to mobilize the pulmonary alveoli, prevent atelectasis, and ensure a proper ventilation/perfusion ratio [46]. Tidal volume lower than $10 \mathrm{ml} / \mathrm{kg}$ results in a drop of FRC (functional residual capacity) and causes the spread of the foci of atelectasis. In turn, a volume higher than $15 \mathrm{ml} / \mathrm{kg}$ causes alveolar distension, increases the resistance in the pulmonary circulation, and reverses blood flow from the lower lung to the upper lung. Such ventilation parameters require high respiratory pressure in order to overcome the decreased compliance of the lower lung, ventilated additionally with high volume through a single lumen of a double-lumen tube [47]. In high frequency ventilation, the peak pressure values oscillate without exceeding $8 \mathrm{~mm} \mathrm{Hg}$, as demonstrated by Misiołek et al. [21]; this is one of the reasons why they can be considered as mini- mally invasive with regard to the "hemostasis" of the cardiovascular system [20]. Based on the still modest number of publications pertaining to this subject, it should be stated that high frequency ventilation should occupy an important position in thoracic surgery procedures, on the one hand as an alternative to one lung ventilation, and on the other, as the treatment of choice in many clinical situations, e.g. it can be an advantageous method of ventilation in patients with impaired circulatory system function.

\section{References}

1. Cohen E. Physiology of lateral position and one-lung ventilation. Chest Surg Clin N Am 1997; 7: 753-757.

2. Kaplan JA. Physiology of the lateral decubitus position, the open chest, and one-lung ventilation. In: Thoracic Anesthesia. Kaplan JA, Slinger PD (eds.). Churchill Livingstone An Imprint of Elsevier Science (USA), Philadelphia 2003; 71-90

3. Abe K, Oka J, Takahashi H. Funatsu T, Fukuda H, Miyamoto Y. Effect of highfrequency jet ventilation on oxygenation during one-lung ventilation in patients undergoing thoracic aneurysm surgery. J Anesth 2006; 20: 1-5.

4. Levin Al, Coetzee JF, Coetzee A. Arterial oxygenation and one-lung anesthesia. Curr Opin Anaesthesiol 2008; 21: 28-36.

5. Garutti I, Quintana B, Olmedilla L, Cruz A, Barranco M, Garcia de Lucas E. Arterial oxygenation during one-lung ventilation: combined versus general anesthesia. Anesth Analg 1999; 88: 494-499.

6. Malbrain ML, Pelosi P, De laet I, Lattuada M, Hedenstierna G. Lymphatic drainage between thorax and abdomen: please take good care of this wellperforming machinery. Acta Clin Belg Suppl 2007; (1): 152-161.

7. Froese AB, Bryan AC. High frequency ventilation. Am Rev Respir Dis 1987; 135: 1363-1374.

8. Ng A, Russell WC, Harvey N, Thompson JP. Comparing methods of adminis tering high-frequency jet ventilation in a model of laryngotracheal stenosis. Anesth Analg 2002; 95: 764-769.

9. Bishop MJ, Benson MS, Sato P, Pierson DJ. Comparison of high-frequency jet ventilation with conventional mechanical ventilation for bronchopleural fistula. Anesth Analg 1987; 66: 833-838.

10. Hautmann H, Gamarra F, Henke M, Diehm S, Huber RM. High frequency jet ventilation in interventional fiberoptic bronchoscopy. Anesth Analg 2000; 90: $1436-1440$

11. Biro P, Eyrich G, Rohling RG. The efficiency of $\mathrm{CO} 2$ elimination during highfrequency jet ventilation for laryngeal microsurgery. Anesth Analg 1998; 87 180-184.

12. Goto K, Goto H, Benson KT, Unruh GK, Arakawa K. Efficacy of high-frequency jet ventilation in cardiac tamponade. Anesth Analg 1990; 70: 375-381.

13. Fritz P, Kraus HJ, Dölken W, Mühlnickel W, Müller-Nolte F, Hering W. Technical note: gold marker implants and high-frequency jet ventilation for stereotactic, single-dose irradiation of liver tumors. Technol Cancer Res Treat 2006; 5: 9-14.

14. Nevin M, Van Besouw JP, Williams CW, Pepper JR. A comparative study of conventional versus high-frequency jet ventilation with relation to the incidence of postoperative morbidity in thoracic surgery. Ann Thorac Surg 1987; 44: 625-627.

15. Misiołek H, Olejnik K, Czyżewski D, Grzanka M, Szczerbak G. The influence of high frequency jet ventilation during lung decortications surgery for selected perioperative parameters. Kardiochir Torakochir Pol 2012; 9: 222-225.

16. Mitzner W, Gioia F, Weinmann GG, Robotham JL, Ehrlich W. Interaction between high frequency jet ventilation and cardiovascular function. Ann Biomed Eng 1987; 15: 319-329.

17. Jenkins J, Cameron EW, Milne AC, Hunter RM. One lung anaesthesia. Cardiovascular and respiratory function compared during conventional ventilation and high frequency jet ventilation. Anaesthesia 1987; 42: 938-943.

18. Fusciardi J, Rouby JJ, Barakat T, Mal H, Godet G, Viars P. Hemodynamic effects of high-frequency jet ventilation in patients with and without circulatory shock. Anesthesiology 1986; 65: 485-491.

19. Misiolek H, Knapik P, Misiolek M, Czyzewski D, Rokicki W. High-frequency ventilation is not suitable for mini-thoracotomy. Eur J Anaesthesiol 2009; 26: 701-702. 
20. Olejnik K, Misiołek H, Czempik P, Szczerbak G, Budziński D, Czyżewski D, Filipowski M. Zastosowanie różnych metod wentylacji do zabiegu odkorowania płuca. Kardiochir Torakochir Pol 2011; 8: 91-95.

21. Misiolek H, Knapik P, Swanevelder J, Wyatt R, Misiolek M. Comparison of double-lung jet ventilation and one-lung ventilation for thoracotomy. Eur J Anaesthesiol 2008; 25: 15-21.

22. Palmers PJ, Vidts W, Ameloot K, Cordemans C, Van Regenmortel N, De Laet I, Schoonheydt K, Dits H, Eichhorn V, Reuter D, Malbrain ML. Assessment of three minimally invasive continuous cardiac output measurement methods in critically ill patients and a review of the literature. Anaesthesiol Intensive Ther 2012; 44: 188-199.

23. Poelaert J, Trouerbach J, De Buyzere M, Everaert J, Colardyn FA. Evaluation of transesophageal echocardiography as a diagnostic and therapeutic aid in a critical care setting. Chest 1995; 107: 774-779.

24. Poelaert J, Schmidt C, Colardyn F. Transoesophageal echocardiography in the critically ill. Anaesthesia 1998; 53: 55-68.

25. Traczyk WZ, Trzebski A. Fizjologia człowieka z elementami fizjologii stosowanej i klinicznej. Wydawnictwo Lekarskie PZWL, Warszawa 2001; 485-486.

26. Poelaert J, Schmidt C, Van Aken H, Hinder F, Mollhoff T, Loick HM. A comparison of transoesophageal echocardiographic Doppler across the aortic valve and thermodilution technique for estimating cardiac output. Anaesthesia 1999; 54: 128-136.

27. Gottschall R, Klein U, Biro P. Past, present and future of jet ventilation. September 20.-21.2002, Jena. Anaesthesist 2003; 52: 74-78.

28. Klein U, Karzai W, Gottschall R. Respiratory gas monitoring during highfrequency jet ventilation for tracheal resection using a double-lumen jet catheter. Anesth Analg 1999; 88: 224-226.

29. Ward KR, Menegazzi JJ, Yealy DM, Klain MM, Molner RL, Goode JS. Translaryngeal jet ventilation and end-tidal PCO2 monitoring during varying degrees of upper airway obstruction. Ann Emerg Med 1991; 20: 1193-1197.

30. Levin A, Coetzee JF, Coetzee A. Arterial oxygenation and one-lung anesthesia. Curr Opin Anaesthesiol 2008; 21: 28-36.

31. Pöyhönen M, Syväoja S, Hartikainen J, Ruokonen E, Takala J. The effect of carbon dioxide, respiratory rate and tidal volume on human heart rate variability. Acta Anaesthesiol Scand 2004; 48: 93-101.

32. Akata T, Noda Y, Takahashi S. Effects of changes in frequency and inspiratory time on arterial oxygenation and $\mathrm{CO} 2$ elimination during high-frequency jet ventilation in a child with laryngotracheal papillomata. Acta Anaesthesiol Scand 2001; 45: 790-792.
33. Spackman DR, Kellow N, White SA, Seed PT, Feneck RO. High frequency jet ventilation and gas trapping. Br J Anaesth 1999; 83: 708-714.

34. Klain $M$, Keszler $H$. Circulation assist by high frequrency ventilation. Crit Care Med 1980; 7: 232

35. Zollinger A. Anesthesia in thoracic surgery. Anaesthesist 1999; 48: 193-204.

36. Nestorowicz A. Kliniczna przydatność wentylacji z wysoką częstotliwością. Wiad Lek 1988; 41: 1366-1369.

37. Nestorowicz A. Wentylacja z wysoką częstotliwością w doświadczalnej niedodmie w warunkach odmy chirurgicznej. Praca habilitacyjna. Akademia Medyczna w Lublinie. Lublin 1989.

38. Marino PL. Intensywna terapia. A. Kübler (eds.). Wydawnictwo Medyczne Urban \& Partner, Wrocław 2001; 3-6.

39. Okada M, Okada M, Ishii N, Yamashita C, Sugimoto T, Okada K, Yamagishi $\mathrm{H}$, Yamashita T, Matsuda $\mathrm{H}$. Right ventricular ejection fraction in the preoperative risk evaluation of candidates for pulmonary resection. J Thorac Cardiovasc Surg 1996; 112: 364-370.

40. Weber A, Mathru M, Rooney MW. Effect of jet ventilation on heart failure: decreased afterload but negative response in left ventricular end-systolic pressure-volume function. Critical Care Med 1996; 24: 647-657.

41. Fusciardi J, Rouby JJ, Barakat T, Mal H, Godet G, Viars P. Hemodynamic effects of high-frequency jet ventilation in patients with and without circulatory shock. Anesthesiology 1986: 65: 485-491.

42. Sherry KM, Windsor JP, Feneck RO. Comparison of the haemodynamic effects of intermittent positive pressure ventilation with high frequency jet ventilation. Studies following valvular heart surgery. Anaesthesia 1987; 42: 1276-1283.

43. Smith RB, Klain M. Experimental high frequency jet ventilation. Int Anesthesiol Clin 1983; 21: 33-50.

44. Spackman DR, Kellow N, White SA, Seed PT, Feneck RO. High frequency jet ventilation and gas trapping. Br J Anaesth 1999; 83: 708-714.

45. Tusman G, Bohm SH, Sipmann FS, Maisch S. Lung recruitment improves the efficiency of ventilation and gas exchange during one-lung ventilation anesthesia. Anesth Analg 2004; 98: 1604-1609.

46. Chen L, Williams JJ, Alexander CM, Ray RJ, Marshall C, Marshall BE. The effect of pleural pressure on the hypoxic pulmonary vasoconstrictor response in closed chest dogs. Anesth Analg 1988; 67: 763-769.

47. Kaplan JA. Lung separation techniques. In: Thoracic Anesthesia. Kaplan JA, Slinger PD (eds.). Churchill Livingstone An Imprint of Elsevier Science (USA), Philadelphia 2003; 159-164. 